\title{
APPLICATION OF PAINTS TO DECREASE AIR PERMEABILITY OF ORIENTED STRAND BOARDS
}

\author{
Matěj Hodoušek ${ }^{1, \star}$, Martin Böhm ${ }^{1}$, Anna Součkován, Miguel Esteban Herrero ${ }^{3}$, \\ Eliška Oberhofnerová ${ }^{1}$
}

\begin{abstract}
The study is focused on the decreasing of oriented strand boards air permeability using paints. The oriented strand boards / 3 (classification according to EN 300:2006) of $12 \mathrm{~mm}$ thickness was chosen for the measurement. Nine different paints were applied in one layer on one side of boards. The difference in air permeability of unpainted and painted boards was defined as paint impact in \%. Paint impact ranged from $1,9 \%$ to $78,6 \%$. Furthermore, the air permeability of 15 and $22 \mathrm{~mm}$ thick oriented strand boards $/ 3$ boards from another producer exhibiting better properties has been measured to compare. The best results of paint impact were obtained for latex paint (paint impact 78,6\%) and penetration 1 (paint impact 66,4\%). Decreasing of the air permeability of oriented strand boards applied in low-cost constructions by using inexpensive paints could significantly improve the insulating properties of the wall structure and thus contribute to the development of the concept of low-cost passive building.
\end{abstract}

Keywords: Airflow, insulation, latex, low-cost, penetration.

\section{INTRODUCTION}

The oriented strand boards (OSB) is a material made of large, flat and oriented strands on the surface and smaller strand fraction inside the board. The surface layers consisting of larger strands provide the main mechanical and physical properties of boards. The production is optimized by adjusting factors such as pressing time, pressure and press closing time. The geometry and arrangement of the strands in surface layers serve also as an important factor influencing the board properties. These production factors determine the physical and mechanical properties of OSB boards (Goroyias and Hale 2004).

The air permeability of OSB depends on its porosity (Al-Hussainy et al. 1966). The more pores the board contains, the higher the air permeability. The content of the pores in the board is determined by the production factors such as the pressing conditions, the strand geometry and the degree of their arrangement (Langmans et al. 2010, Gaete-martinez 2008). The air permeability values also differ depending on the producer (Langmans et al. 2010), the air pressure difference on both sides of the board (Kumaran et al. 2003), the thickness and the type of board (Kumaran et al. 2003, Hodoušek et al. 2015) and the nature of the air/board boundary conditions. The OSB board is frequently discussed within technical web sites dealing with the building industry and the construction of residential houses. Since the water vapor permeability and air permeability of OSB and their dependence on type, thickness and

\footnotetext{
${ }^{1}$ Department of Wood Products and Wood Constructions. Faculty of Forestry and Wood Sciences, Czech University of Life Sciences Prague. Kamycka, Prague, Czech Republic.

${ }^{2}$ Timber Research and Development Institute, Prague, Czech Republic.

${ }^{3}$ Department of Forest and Environmental Engineering and Management ETSI Montes, Technical University of Madrid, Madrid, Spain.

•Corresponding author: hodousek@fld.czu.cz
}

Received: 10.11.2017 Accepted: 28.07.2018 
producer has been demonstrated (Li 2007, Mukhopadhyaya and Kumaran 2007), different materials and coatings are used in the combination with OSB board to improve its insulating properties. It is often recommended to apply the primer, followed by latex paint or to apply the latex paint only (Glass et al. 2016). This combination was found to be effective in terms of the emission of volatile substances (Bartekova et al. 2006). Testing both of these paints is a part of this study.

Adjusting the air permeability of the boards can be accomplished either during the production process by pressing parameters setting and by using a suitable input material, or by decreasing the air permeability of the finished boards by adding another cover layer on the surface of the board. In the past, different foils and systems influencing both air and water vapor permeability have been developed on the polymer basis, not only for OSB application (Fay 2010, Russell 2017), on the silicone basis (Huda et al. 2015) and in the form of vacuum-applied metal layer (O'rourke et al. 2010). Langmans et al. (2010) used an asphalt coating during his attempt to reduce air permeability of the fiberboard. The effort is to decrease the air permeability of the boards, especially in the case of the producers of more permeable boards, and thereby to decrease the total air leakage through the building structure. The meaningful effort is to find materials allowing air permeability decrease without enforcing even more demanding application or large expense. The aim of this study is to determine the influence of application of some commonly available paints on the air permeability of the OSB and thus to contribute to the development of the concept of low-cost civil engineering in the field energy-efficient wood buildings.

\section{MATERIALS AND METHODS}

\section{OSB specification}

The widely used type of board for construction purposes, OSB/3 with a thickness of $12 \mathrm{~mm}$, has been selected for this experiment. The boards were obtained from a domestic OSB producer (producer 1). The production characteristics of the boards are listed in the following Table 1:

Table 1: Production characteristics of the OSB/3 test specimens.

\begin{tabular}{|c|c|c|}
\hline Conditions & $\begin{array}{c}\text { OSB } / 3 \\
\text { Surface layers }\end{array}$ & $\begin{array}{c}\text { OSB } / 3 \\
\text { Core }\end{array}$ \\
\hline $\begin{array}{l}\text { Pressure }\left(\mathrm{N} / \mathrm{mm}^{2}\right) \\
\text { Pressing temperature }\left({ }^{\circ} \mathrm{C}\right) \\
\text { Pressing factor }(\mathrm{s} / \mathrm{mm}) \\
\text { Used adhesive } \\
\text { Adhesive amount }\left(\mathrm{kg} / 1 \mathrm{~m}^{3} \text { board, dry matter) }\right. \\
\text { Paraffin }\left(\mathrm{kg} / 1 \mathrm{~m}^{3} \text { board) }\right. \\
\text { Paraffin emulsion }(\%) \\
\mathrm{H}_{2} \mathrm{O}\left(1 / 1 \mathrm{~m}^{3} \text { board) }\right. \\
\mathrm{H}_{2} \mathrm{O} \text { (dosing to the desired strand moisture) } \\
\mathrm{Hardener} \\
\text { Wood material ( } \mathrm{kg} / 1 \mathrm{~m}^{3} \text { board, atro, } \\
\text { softwoods) } \\
\text { Used raw material } \\
\text { MUF, MDI concentration } \\
\text { Hardener concentration } \\
\text { Paraffin emulsion concentration }\end{array}$ & $\begin{array}{c}\text { MUF } \\
35,(8,5 \%)^{*} \\
1,2 \\
10,5 \% \\
2,4 \% *\end{array}$ & 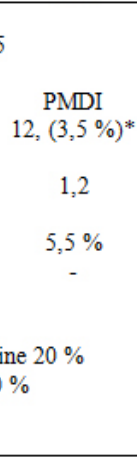 \\
\hline
\end{tabular}

The strands used for the production were separated with a screen (openings of 3,5 x $30 \mathrm{~mm}$ ), using a surface/core strands ratio of 50/50. The average density of boards was $568 \mathrm{~kg} / \mathrm{m}^{3}$.

\section{Preparation of samples}

All test specimens were made in $1200 \times 1200 \mathrm{~mm}$ format allowing clamping into test chamber with dimensions of $1000 \times 1000 \mathrm{~mm}$. They were conditioned in a test conditions $\left(11,4^{\circ} \mathrm{C} ; 60 \%\right.$ relative air 
humidity).

\section{Application of paints}

The nine different paints were applied on one side of OSB by brush to cover all visible parts, gaps and pits in the board surface. Detail specification of the used paints is given in Table 2. The weight of the paint, given in Table 3, was determined by the difference in sample weight before and after paint application. The mean density of the boards after paint application increased to $608 \mathrm{~kg} / \mathrm{m}^{3}$.

Table 2: Specification of tested paints.

\begin{tabular}{|c|c|c|c|}
\hline $\begin{array}{l}\text { No. of } \\
\text { sample }\end{array}$ & Paint type & Specification & $\begin{array}{l}\% \text { of } \\
\text { weight }\end{array}$ \\
\hline \multirow[t]{3}{*}{1} & \multirow[t]{3}{*}{ Silicate fasade paint } & Potassium silicate & $<7$ \\
\hline & & Silica & $<7$ \\
\hline & & Potassium methylsilanolate & $<1,5$ \\
\hline \multirow[t]{2}{*}{2} & \multirow[t]{2}{*}{ Silicone fasade paint } & $\begin{array}{l}\text { Siloxane and silicone, [3-[(2-Amino- } \\
\text { ethyl)amino]propyl]methyl ether }\end{array}$ & $<1$ \\
\hline & & Reaction mixture & $<0,0014$ \\
\hline \multirow[t]{2}{*}{3} & \multirow[t]{2}{*}{$\begin{array}{l}\text { Acrylate } \\
\text { facade paint }\end{array}$} & $\begin{array}{l}\text { Carbohydrates, C09-C11, n-alkanes, } \\
\text { isocyanates, cyclic, }<2 \% \text { aromatics }\end{array}$ & $<3$ \\
\hline & & Reaction mixture & $<0,0014$ \\
\hline \multirow[t]{2}{*}{4} & \multirow{2}{*}{$\begin{array}{l}\text { Polyurethane } \\
\text { varnish }\end{array}$} & 2-Butoxyethan-1-ol; Butyl glycol & $<5$ \\
\hline & & $\begin{array}{l}\text { 1-methyl-2-pyrrolidone } \\
\text { Reaction mixture }\end{array}$ & $\begin{array}{l}<5 \\
<0,0014\end{array}$ \\
\hline \multirow[t]{4}{*}{5} & \multirow[t]{4}{*}{ Waterborne email } & Silica & $<6$ \\
\hline & & 2- (2-Butoxyethoxy) ethanol Butyl diglycol & $<2$ \\
\hline & & 2-Butoxyethan-1-ol; Butyl glycol & 1 \\
\hline & & Reaction mixture & $<0,0014$ \\
\hline 6 & Latex paint & $\begin{array}{l}\text { A mixture of white pigment, fillers, additives } \\
\text { and fungicides dispersed in a water dispersion } \\
\text { of macromolecular substances (content of non- } \\
\text { volatile compounds -min. } 58 \% \text {, density - } 1400 \\
\mathrm{~kg} / \mathrm{m}^{3} \text { ) }\end{array}$ & \\
\hline 7 & Penetration 1 & $\begin{array}{l}\text { Water dispersion of styreneacrylate copolymer } \\
\text { (viscosity } 70 \mathrm{mPa} \text {.s, dry } 10+/-2 \% \text { ) }\end{array}$ & \\
\hline 8 & Penetration 2a & $\begin{array}{l}\text { Water dispersion of styreneacrylate copolymer } \\
1010 \mathrm{~kg} / \mathrm{m}^{3}, 10 \% \text { content of non-volatile compo }\end{array}$ & $\begin{array}{l}\text { lensity - } \\
\text { unds) }\end{array}$ \\
\hline 9 & Penetration $2 b$ & $\begin{array}{l}\text { Water dispersion of styreneacrylate copolymer ( } \\
1250 \mathrm{~kg} / \mathrm{m}^{3}, 25 \% \text { content of non-volatile compo }\end{array}$ & $\begin{array}{l}\text { lensity - } \\
\text { unds) }\end{array}$ \\
\hline
\end{tabular}

Reaction mixture - (3:1): 5-chlorine-2-methylisothiazole-3(2H)-on a 2-methylisothiazole-3(2H)-on.

For the project purpose, the paint materials that are commonly available on the construction market were used. Three penetration coatings have been chosen for a closer examination of the influence of penetration on the air permeability. Penetration coatings are commonly used for filling the porous surfaces before the application of topcoat. Penetration 1 is the type commonly available under the designation $2802 \mathrm{~A}$ at a concentration of $100 \%$. Penetration $2 \mathrm{a}$ is a penetration coating from another producer with a protected composition, and Penetration $2 \mathrm{~b}$ represents a penetration coating $2 \mathrm{a}$ with an increased dry matter content to achieve a higher filling ability. After paint application, the drying followed. The samples were naturally dried, out of direct sunlight, for a minimum time of 48 hours, in mean ambient conditions of $10,3^{\circ} \mathrm{C}, 60 \%$ relative humidity and an atmospheric pressure of $965 \mathrm{hPa}$.

\section{Air permeability test}

The air permeability test was performed before and after paint application on three samples per each group made from original test boards in certified laboratory in the airtight chamber FPS 3525/450 MSD-digital PC (K. Schulten Fenstertechnik). The test samples were subjected to a set of graduated pressure differences (positive and negative) while the airflow value at each level of pressure difference was measured. The maximum and minimum pressures were set to $600 \mathrm{~Pa}$ and $50 \mathrm{~Pa}$, respectively. 
After placing the sample into the test chamber using clamping devices, a positive pressure differences of $50,100,150,200,250,300,450,600 \mathrm{~Pa}$ were applied and the airflow volume was measured for each pressure difference in $\mathrm{m}^{3} / \mathrm{h}$. The same procedure for negative pressure differentials followed. All measured values were converted to reference conditions according to the following Equation 1, as stated in EN 12114:2000. Air permeability expressed as a quotient of airflow $g_{a}\left(\mathrm{~m}^{3} / \mathrm{m}^{2} / \mathrm{h}\right)$ and pressure difference $\Delta \mathrm{Pa}(\mathrm{Pa})$ according to the following equation was calculated (Hens 2017):

$$
K_{a}=\frac{g_{a}}{\Delta P_{a}}\left[m^{3} / m^{2} / h / P a\right]
$$

where $K_{a}$ is an air permeability converted to $1 \mathrm{~m}^{2}$ of the board and $1 \mathrm{~Pa}$ of the pressure difference. The difference in air permeability of painted and unpainted samples is expressed as a percentage.

\section{Statistical evaluation}

The measured and calculated values were subjected to statistical analysis in STATISTICA software (StatSoft, USA). Statistically significant differences between the air permeability of samples before and after paint application were determined by ANOVA and by Tukey's honest significant difference test.

\section{RESULTS AND DISCUSSION}

$\mathrm{OSB} / 3$ boards were subjected to air permeability tests according to the aforementioned conditions. Mean air permeability values per $1 \mathrm{~m}^{2}$ of the board are listed in the following Table 3, including the coefficient of variation for each group. The results for the unpainted samples are represented by Mean value - OSB and after painting by Mean value - painted. Paint impact indicates the increase of the air permeability of the sample after paint application in percentages.

Table 3: Mean values of air permeability.

\begin{tabular}{ccccccc}
\hline Sample & $\begin{array}{c}\text { Paint } \\
\text { weight (g) }\end{array}$ & $\begin{array}{c}\text { Mean } \\
\text { value - } \\
\text { OSB }\end{array}$ & $\begin{array}{c}\text { COV } \\
\text { (\%) }\end{array}$ & $\begin{array}{c}\text { Mean value } \\
\text { - painted }\end{array}$ & $\begin{array}{c}\text { COV } \\
\text { (\%) }\end{array}$ & $\begin{array}{c}\text { Paint } \\
\text { impact } \\
(\%)\end{array}$ \\
\hline 1 & 273 & 0,0237 & 14,6 & 0,0114 & 18,4 & 52,0 \\
2 & 179 & 0,0235 & 23,9 & 0,0102 & 21,0 & 56,4 \\
3 & 217 & 0,0219 & 11,6 & 0,0096 & 19,1 & 56,1 \\
4 & 132 & 0,0206 & 15,4 & 0,0138 & 23,9 & 33,2 \\
5 & 168 & 0,0216 & 15,3 & 0,0132 & 19,5 & 38,8 \\
6 & 219 & 0,0219 & 11,2 & 0,0047 & 18,6 & 78,6 \\
7 & 160 & 0,0246 & 12,1 & 0,0083 & 34,9 & 66,4 \\
8 & 143 & 0,0196 & 10,1 & 0,0192 & 11,6 & 1,9 \\
9 & 160 & 0,0167 & 12,0 & 0,0119 & 12,8 & 28,7 \\
\hline
\end{tabular}

COV - Coefficient of variation, 1-Silicate fasade paint, 2-Silicone fasade paint, 3-Acrylate facade paint, 4-Polyurethane varnish, 5-Waterborne email, 6-Latex paint, 7-Penetration 1, 8-Penetration 2a, 9-Penetration 2b

From the table values (Table 3 ), the greatest influence of latex paint $(78,6 \%)$ on the air permeability of OSB boards was observed, while the slightest one was noted for Penetration $2 \mathrm{a}(1,9 \%)$. In the case of penetration 2a, the application due to its low viscosity was more difficult. High water content made it difficult to apply on the paraffin hydrophobic layer of the boards and the penetration process 
required more careful and demanding work. Surprisingly, Penetration 1 reached the second biggest effect $(66,4 \%)$ on the air permeability. The silicone and acrylate based facade paints caused more than half decrease of air permeability $(52,56,4$ and $56,1 \%)$, polyurethane varnish and email reduced the air permeability with the paint impact of $33,2 \%$ and $38,8 \%$ respectively. The polyurethane varnish should theoretically completely close the surface of the board, however, it did not happen due to the low viscosity and the considerable uneven board surface. The difference in the paint impact of penetration $2 \mathrm{a}$ and $2 \mathrm{~b}$ shows that air permeability is more influenced by a paint with a higher content of fillers. However, the difference between the paint impact of penetration 1 and penetration $2 \mathrm{a}$ shows that the producer and type of penetration also have a significant effect on the ability of the paint to decrease air permeability. Regarding coefficient of variation, a slight increase in the case of painted samples was observed. Application of several layers of paint would help to multiply the effect, but the purpose of this study is to determine the differences between the selected paints. For the comparison of air permeability results in the area of all pressure differences, the ANOVA analysis of $\mathrm{K}_{\mathrm{a}}$ permeability values was done. The results are shown in Figure 1 below:

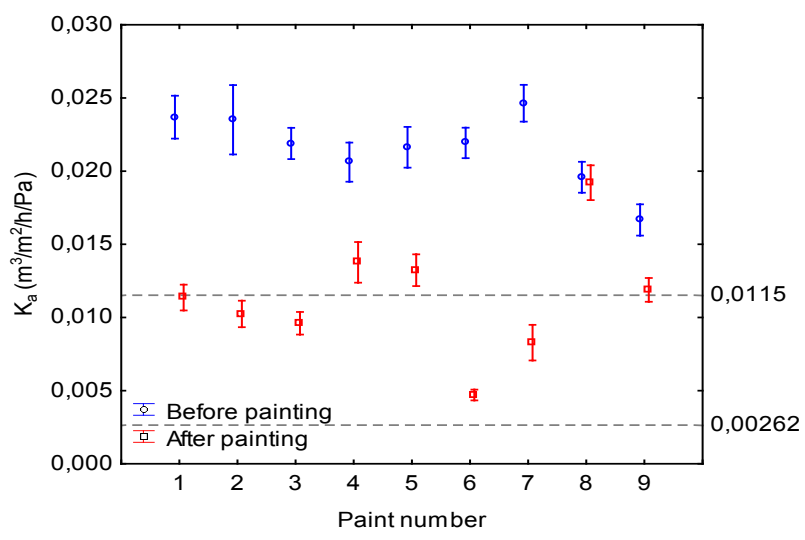

Figure 1: Graphic result of ANOVA analysis of air permeability of samples before and after paint application. 1-Silicate fasade paint, 2-Silicone fasade paint, 3-Acrylate facade paint, 4-Polyurethane varnish, 5-Waterborne email, 6-Latex paint, 7-Penetration 1, 8-Penetration 2a, 9-Penetration 2b.

The measured mean values and variances of specific paint types are shown in Figure 1. Paints are identified by the number (1-9) according to Table 2. Each type of paint is represented by two data series - before and after application. The significant difference in these values can be observed for paint No. 6 - the latex paint, which is characterized by the smallest variance of measured values after paint application. On the contrary, the slightest paint impact was determined for paint No.8 Penetration 2a, whose values of air permeability before and after paint application are almost equal. For the quantification of the air permeability differences between unpainted and painted samples, the analysis of variance (ANOVA) and subsequent test of honest significant difference (Tukey's HSD test) were used. Statistically significant differences (at the alpha $=0,05$ level) in the air permeability before and after paint application was observed in almost all the cases. Only in the case of Penetration 2a, the statistically significant difference was not detected (p-value of Tukey's HSD test was 0,622).

There are two reference lines for the air permeability values of 0,0115 and 0,00262 (Figure 1). These values were measured for the OSB from another producer, who is characterized by production of boards with significantly better properties compared to the boards used in this experiment (1-9). The value of 0,0115 represents the mean value of air permeability of raw OSB/3 board $15 \mathrm{~mm}$ thick and the value 0,00262 value represents the air permeability of OSB/3 board with the thickness of $22 \mathrm{~mm}$. It can be noted from the graph that application of more than half of the different paints decreased the air permeability of OSB/3 (12 mm thick) below the air permeability value of thicker board of higher quality. None of the tested paints decreased the permeability value to the limit corresponding to the 22 $\mathrm{mm}$ thick OSB $/ 3$ board from another producer. To decrease the air permeability under the 0,0115 line, more coating layers should be applied. Also the use of thicker boards could significantly decrease the 
air permeability.

Latex is a compound often used in the construction. In the past, the satisfactory results of latex paints in the field of wood protection against biotic factors, weathering and fire were recorded (Hao and Chow 2003). The influence of latex paint on the air permeability results enables its possible wider application. Commonly used latex paints combine latex with other additives for paint modification. The latex paint only is rather used as an external and protective topcoat. In the case of latex paint application on the raw OSB, it would be necessary to consider an application of other building materials contained in the wall structure and their adhesion to latex paint. On the contrary, the penetration is used as the first penetrating layer, which prepares the underlying material for the application of other layers. Based on the results, it can be concluded that each producer of penetration type coatings uses different process during production. The main difference between penetration 1 and $2 \mathrm{a}$ is the water content. Penetration 2a contains lower portion of dry matter and is characterized by lower viscosity. When applied on raw wood, for example, this difference would signify a different depth of penetration. Rijckaert et al. (2001) measured the deeper penetration of the modified penetration coating with the lower content of dry matter. Anyway, from the point of view of air permeability, it is more convenient to use penetration with the higher content of filling agents. Regarding the interaction with other materials in the construction, the penetration is very compatible with other coatings and compounds. The penetration is often used for the filling of pits and surface preparation, but also for the protection against biotic factors (Ozgenc et al. 2012). In this study, one of the used penetrations was the water dispersion of styrene-acrylate copolymer (paint No. 7), which is available on the market at an affordable price. More than $66 \%$ decrease in air permeability after its application is a very optimistic result, which can be the starting point for the use of penetration to decrease air permeability. However, the weathering of paints and subsequent degradation of their properties have to be considered as well. Application of topcoat is supposed to be done subsequently after the surface preparation using penetration, but often happens that the time period between the application of penetration and topcoat is longer, and the penetrated surface is exposed to weathering, which has negative effect on the properties of the topcoat (Barra and Valcarel 1989). Application of paint layer on the penetrated surface exposed to weathering is followed by the decrease in coating adhesion caused by the loss of surface tension of penetration layer (White 1984). This effect can have the negative influence on the air permeability due to the loss of tension of penetration, which fills the cavities formed on the board surface. Williams et al. (2008) studied the possibilities of preventing the properties of weathered penetration coating using the surface pretreatment before application of topcoat. All the samples used in the study of Williams et al. (2008) showed deterioration in properties to a greater or lesser extent. When applying penetration, it needs to remember that the longer exposure of penetrated material without topcoat to weathering has a negative effect on final properties of applied topcoat.

Considering the improvement of air permeability of building materials, there are two ways of approach, either to use the OSB of higher quality and price or the lower-cost variant of the board with subsequent application of paints. Similar properties are reached, with different acquisition costs. However, when applying topcoat to improve properties of the boards, the degradation of applied paint layers exposed to weathering has to be considered. The decrease of air permeability of OSB used for low-cost constructions by application of inexpensive paints enabling the subsequent application of other building materials, mostly PUR foam, could significantly the improvement of the insulating properties of the wall structure and contribute to the development of low-cost passive building concept. More options in better board properties are opened by using different raw material or different paints that results in better mechanical and physical properties of oriented strand board (Pecho et al. 2004, Garay and Henriquez 2010).

\section{CONCLUSIONS}

Based on the conducted tests and obtained results, the air permeability of OSB can be decreased by paint application. In order to reduce acquisition costs, available and inexpensive paint materials were tested in this study. 
The latex paint had the greatest influence on the air permeability $(78,6 \%$ decrease $)$, the penetration No. 1, commonly known as $2820 \mathrm{~A}$, produced the second best result (66,4 \% decrease). In the case of penetration 2 , the change in air permeability of painted boards was related to change of fillers content. From this perspective it seems that air permeability could be adjusted by adding filling agents. But further investigation has to be done in this field.

Application of paint to decrease air permeability can significantly improve insulating properties of boards of lower quality and acquisition costs compared to use of more expensive boards of higher quality.

The air permeability of OSB can be by means of paint application decreased to the level of air permeability of thicker boards with better production parameters while maintaining minimal costs.

\section{ACKNOWLEDGEMENTS}

The authors are very grateful for the financial support of the Grant Agency of Faculty of Forestry and Wood Sciences, Project No. B_04_17: Advanced methods for modification of the physical and mechanical properties of particle boards.

\section{REFERENCES}

Al-Hussainy, R.; Ramey Jr. H.J.; Crawford, P.B. 1966. The flow of real gases through porous media. Journal of Petroleum Technology 18(05):624-636.

Bartekova, A.; Lungu, C.; Shmulsky, R.; Huelman, P.; Park, J.Y. 2006. Laboratory evaluation of volatile organic compounds emissions from coated and uncoated oriented strandboard. Forest Products Journal 56(2):85-90.

Barra, M.R.D.; Valcarcel, A.I.G. 1989. Imprimaciones para la protección temporal de maderas ante la intemperie. Instituto Nacional de Investigaciones Agrarias. No. CIDAB-: S254-In8t-16/89.

European standard. EN. 2000. Thermal performance of buildings - Air permeability of building components and building elements - Laboratory test method. EN 12114. 2000.

European standard. EN. 2006. Oriented Strand Boards (OSB) - Definitions, classification and specifications. EN 300. 2006.

Fay, R.M. 2010. Spray applied building wrap coating material, spray applied building wrap, and building construction assembly. U.S. Patent No 7,662,221.

Gaete-Martinez, V.; Shaler, S.M.; Russell, E.; Hill, J. 2008. Effect of strand geometrical distribution (SGD) in oriented strand composite (OSC) formation quality. Proceedings of the $51^{\text {st }}$ International Convention of Society of Wood Science and Technology, Chile. Paper WS-62, p.10.

Garay, R.; Henriquez, M. 2010. Comportamiento frente al fuego de tableros y madera de pino radiata con y sin pintura retardante de llama. Maderas-Ciencia Tecnol 12(1): 11-24.

Glass, S.V.; Yeh, B.; Herzog, B.J. 2016. Effects of exterior insulation on moisture performance of wood-frame walls in the Pacific Northwest: measurements and hygrothermal modeling. In: Proceedings of the $3^{\text {rd }}$ Residential Building Design \& Construction Conference, University Park, PA, USA. p 292311.

Goroyias, G.J.; Hale, M.D. 2004. The mechanical and physical properties of strand boards treated with preservatives at different stages of manufacture. Wood Science and Technology 38(2):93-107. 
Hao, J.; Chow, W.K. 2003. A brief review of intumescent fire retardant coatings. Architectural Science Review 46(1):89-95.

Hens, H.S.L. 2017. Building physics-heat, air and moisture: fundamentals and engineering methods with examples and exercises. John Wiley \& Sons. ISBN 3433608571

Hodoušek, M.; Böhm, M.; Lemaster, R.L.; Bureš, M.; Beránková, J.; Cvach, J.

Air Permeation Rate of Oriented Strand Boards (OSB/3 and OSB/4). BioResources 10(1):11371148 .

Huda, F.; Ahmed, F.; Johansen, J. J.; Mistry, B.; McConnery, C.W. 2015. Air-water barrier silicone coatings. U.S. Patent Application No 15/114,421.

Kumaran, M.K.; Lackey, J.; Normandin, N.; Tariku, F.; Reenen, V.D. 2003. Variations in the hygrothermal properties of several wood-based building products. Research in building physics. Lisse, The Netherlands: Swets and Zeitlinger, 35-42.

Langmans, J.; Eykens, P.; Klein, R.; Roels, S. 2010. Air permeability requirements for air barrier materials in passive houses-Comparison of the air permeability of eight commercial brands of OSB. In: $5^{\text {th }}$ International Symposium on Building and Ductwork Air-tightness, Copenhagen. p. 9.

Li, H. 2007. A modeling and experimental investigation of coupled heat, air, moisture and pollutants transport in building envelope systems. Syracuse University. ISBN: 0549410163

Mukhopadhyaya, P.; Kumaran, M.K. 2007. Heat-air-moisture transport: Measurements on building materials. ASTM STP 1495. ISBN 978-0-8031-3422-5

O`Rourke, K.B.; Katsaros, J.D.; Bletsos, I.V. 2010. Durable metallized self-adhesive laminates. U.S. Patent No 7,641,952.

Ozgenc, O.; Hiziroglu, S.; Yildiz, U.C. 2012. Weathering properties of wood species treated with different coating applications. BioResources 7(4): 4875-4888.

Pecho, R.; Ananias, R.A.; Ballerini, A.; Cloutier, A. 2004. Influencia de la madera juvenil de pino radiata sobre las propiedades mecánicas de tableros OSB. Maderas-Cienc Tecnol 6(1): 45-59.

Rijckaert, V.; Stevens, M.; Acker, V.J. 2001. Effect of some formulation parameters on the penetration and adhesion of water-borne primers into wood. European Journal of Wood and Wood Products 59(5):344-350.

Russell, A. 2017. Adhesive membrane. U.S. Patent No. 9,562,174. Washington, DC: U.S. Patent and Trademark Office.

White, J.H. 1984. Intercoat adhesion in epoxy paint systems. Proceedings $11^{\text {th }}$ World Congress on Metal Finishing, Jerusalem, Israel. October 21-26. p. 280-287.

Williams, R.S.; Knaebe, M.; Sotos, P. 2008. Effect of surface preparation on service life of topcoats applied to weathered primer paint. PRA's 6th International Woodcoatings Congress „preserve, protect, prolong“", Amsterdam, Netherlands, 14-15 October 2008, 16 p. 